\title{
Introduction
}

Foreign direct investments are an important part of today's globally integrated economy. Their popularity and level have dramatically risen since the 199os, when technological advances and the demise of the Soviet Union fueled the trend towards globalization. Foreign direct investments take on many forms. They are characterized by the acquisition of virtually any kind of asset that creates a lasting interest by a foreign national in another State. The acquired asset can be a physical one, such as a building, factories, machines or equipment, or it can be a portion of a foreign company's shares. ${ }^{1}$ Currently, most foreign direct investments are made in the services sector. ${ }^{2}$ In terms of industries, the extractive industry, the electric power industry, transportation, construction and finance are particularly attractive. ${ }^{3}$ Foreign investors are frequently involved in providing public services in their host countries, such as operating water and sanitation systems, electricity plants, telecommunication services or public transportation systems. In the past, foreign direct investments have allowed developing countries to tap foreign financial sources and know-how to support their industrialization process. Investors, on the other side, were able to gain access to new markets.

Foreign investors are particularly vulnerable to government interference with their operations. They invest with a view to a long term operation, and therefore take substantial sunk costs. At the same time, their inability to participate in the democratic process in their host State makes it difficult to foresee government actions. Accordingly, they have a heightened interest in the stability and predictability of the regulatory environment in their host State. ${ }^{4}$

1 Doak Bishop, James Crawford \& W. Michael Reisman, Foreign Investment Disputes: Cases, Materials and Commentary 9 (2nd ed. 2014); Andrew Newcombe \& Lluís Paradell, Law and Practice of Investment Treaties: StanDARDS OF TREATMENT 91 (2009).

2 United Nations Conference on Trade and Development, World Investment Report 2015, at 12, UNCTAD/WIR/2015 (June 25, 2015) [hereinafter UNCTAD, WIR 2015]; Organisation for Economic Co-operation and Development, OECD International Direct Investment Statistics 2014, at 15, available at http://dx.doi.org/10.1787/idis-2014-en.

3 UNCTAD, WIR 2015, supra note 2, at 13-14; International Centre for Settlement of Investment Disputes, The ICsID Caseload-Statistics (Issue 2016-1), at 12, https://icsid.worldbank.org/apps/ ICSIDWEB/resources/Documents/ICSID\%2oWeb\%2oStats\%202016-1\%20(English)\%2ofinal.pdf [hereinafter ICSID, Caseload-Statistics 2016-1].

4 Aron Broches, The Convention on the Settlement of Investment Disputes Between States and Nationals of Other States, RECUEIL DES CouRs 331, 343 (1972). 
International investment agreements (IIAs) and bilateral investment treaties (BITs) satisfy those interests by protecting foreign investors from a range of adverse regulatory actions by host States. They contain definitions of the kinds of investments covered, and specify the substantive standards of protection they afford. Along with the spike in international investment in the second half of the 1990s, a particularly high number of BITs were entered into. ${ }^{5}$ Even today, their number is still growing, ${ }^{6}$ though not at as high a rate.

The substantive protection afforded by BITs and IIAs is procedurally enforceable pursuant to the dispute resolution clauses contained in such agreements. These clauses usually provide for the settlement of disputes between an investor and a host State (so-called investor-State dispute settlement, or ISDS) by arbitration (investor-State arbitration). ${ }^{7}$ For example, arbitration is the dispute settlement mechanism of choice in the U.s. Model BIT,${ }^{8}$ in Swiss BITs, ${ }^{9}$ in the North American Free Trade Agreement ${ }^{10}$ and in the Energy Charter Treaty. ${ }^{11}$ Today, arbitration under the Convention on the Settlement of Investment Disputes between States and Nationals of other States ${ }^{12}$ is the most important

5 United Nations Conference on Trade and Development, World Investment Report Overview 2015: Reforming International Investment Governance, at 24 fig.10, UNCTAD/ WIR/2015(Overview) (June 25, 2015); Christoph H. Schreuer, The Dynamic Evolution of the ICsid System, in The International Convention on the Settlement of InvestMENT DispUtes (ICSID) 15, 20 (Rainer Hofmann \& Christian J. Tams eds., 2007) [hereinafter Schreuer, Dynamic Evolution]; Antonio R. PArra, The History of ICSID 199 (2012). United Nations Conference on Trade and Development, IIA Issues Note: Recent Trends in IIAS and ISDS, No. 1 (Feb. 2015), at 2, http://unctad.org/en/PublicationsLibrary/ webdiaepcb2015di_en.pdf.

7 Gus Van Harten, Investment Treaty Arbitration and Public LaW 3 n.10 (2007) [hereinafter Van Harten, Investment Treaty Arbitration]. The terms investor-State dispute settlement, investor-State arbitration, investment treaty arbitration, and investment arbitration are often used interchangeably.

2012 U.s. Model Bilateral Investment Treaty, available at http://www.state.gov/documents/organization/188371.pdf (last accessed on Dec. 30, 2016).

See, e.g., Agreement on the Promotion and Reciprocal Protection of Investments, Switz.China, art. 11, para. 2, Jan. 27, 2009, AS 2010 1717; Agreement for the Promotion and Protection of Investments, Switz.-India, art. 9, para. 3, Apr. 4, 1997, AS 2002 2037; Agreement on the Promotion and Reciprocal Protection of Investments, Switz.-Venez., art. 9, para. 2, Nov. 18, 1993, AS 1999 2149; Agreement concerning the Promotion and Reciprocal Protection of Investments, Switz.-Malay., art. 9, para. 2, AS 1978 1183.

10 North American Free Trade Agreement, U.s.-Can.-Mex., art. 1120, Dec. 17, 1992, 32 I.L.M. 289 (1993) [hereinafter NAFTA].

11 The Energy Charter Treaty, art. 26, para. 2 (c) and 4, Dec. 17, 1994, 34 I.L.M. 381 (1995) [hereinafter ECT].

12 Convention on the Settlement of Investment Disputes Between States and Nationals of Other States, Mar. 18, 1965, 17 U.S.T. 1270 (entered into force Oct. 14, 1966) [hereinafter 
ISDS mechanism. ${ }^{13}$ The Convention was adopted in 1965, and established the International Centre for Settlement of Investment Disputes (ICSID) as one of the five organizations of the World Bank Group. ${ }^{14}$

Like other ISDS mechanisms, the ICSID Convention does not contain rules on investors' substantive rights, but provides disputing parties with a procedural mechanism for the resolution of investment disputes. ${ }^{15}$ Investment arbitration under the ICSID Convention allows investors to bring claims directly against their host States, ${ }^{16}$ while evading the potentially biased courts in their host States, and avoiding reliance on their home States' discretionary exercise of diplomatic protection. By replacing the "gunboat diplomacy" formerly used to resolve investment disputes, and instead assessing competing legal claims in an independent and neutral manner, ${ }^{17}$ ICSID arbitration de-politicizes such controversies and advances the rule of law. ${ }^{18}$

the Washington Convention, the ICsid Convention or the Convention]. Disputes which are governed by the ICSID Convention are also subject to the ICSID Rules of Procedure for Arbitration Proceedings [hereinafter the ICSID Arbitration Rules or the Arbitration Rules].

13 See UnCTAD, WIR 2015, at 114, UNCTAD/WIR/2015 (June 25, 2015); Meg Kinnear \& Frauke Nitschke, Disqualification of Arbitrators under the ICSID Convention and Rules, in CHALLenges and Recusals of Judges and Arbitrators in International Courts and Tribunals 34, 34 (Chiara Giorgetti ed., 2015); Lucy Reed, Jan Paulsson \& Nigel Blackaby, Guide to icsid Arbitration 6-7 (2nd ed. 2011); Rainer Hofmann \& Christian J. Tams, Introduction: The International Convention on the Settlement of Investment Disputes (ICSID) - Taking Stock after 40 Years, in The International Convention on the Settlement of Investment Disputes (ICSid), 9 (Rainer Hofmann \& Christian J. Tams eds., 2007).

14 Reed, Paulsson, and Blackaby, supra note 13, at 9.

15 After long and unsuccessful attempts to agree on uniform substantive standards of investment protection in other international fora, such a goal was not even pursued during the drafting process. See id. at 2; Broches, supra note 4, at 343-344.

16 See Christoph H. Schreuer et Al., The icsid Convention - A Commentary ix (2nd ed. 2009) [hereinafter Schreuer et Al., Commentary]; Schreuer, Dynamic Evolution, supra note 5, at 16.

17 Catherine A. Rogers, The Politics of International Investment Arbitrators, 12 SANTA Clara J. InT'L. L. 233, 226 (2013) [hereinafter Rogers, Politics]; Stephan W. Schill, Private Enforcement of International Investment Law, in The BACKLASH Against Investment Arbitration 29, 31 (Michael Waibel et al. eds., 2010); Reed, Paulsson, and BlackaBY, supra note 13, at 4-5; Catherine A. Rogers, International Arbitration in a Time of Global Upheaval, Kluwer Arbitration Blog (Sept. 17, 2014), http://kluwerarbitrationblog.com/ blog/2014/og/17/international-arbitration-in-a-time-of-global-upheaval/ [hereinafter Rogers, Global Upheaval].

18 Broches, supra note 4, at 343; David W. Rivkin, The Impact of International Arbitration on the Rule of Law, 29 АRв. INT'L. 327, 341 (2013). 
The ICSID Convention's focus on procedural empowerment instead of substantive protection is based on the idea that procedural settings shape substantive outcomes, ${ }^{19}$ without predetermining them. A neutral, law-based proceeding ensures that decisions are not reached in an environment of arbitrariness. ${ }^{20}$ In the complex policy setting of investment disputes, ${ }^{21}$ where decisions on investor-State claims are unlikely to ever satisfy all participants, the parties' buy-in largely depends on their confidence in the mechanism's fairness. The parties' acceptance of and compliance with an unfavorable award is more likely in the absence of doubts about procedural fairness. ${ }^{22}$ Legitimacy, thus framed, does not lie in the outcome of a procedure, but in the perception of the award's procedural integrity. ${ }^{23}$

The procedural fairness of the arbitral system is primarily dependent on its decision-makers. Thus, the requirement of arbitrators' independence and impartiality is "obvious and imperative," 24 and common to all major arbitration

19 Giacinto della Cananea, Minimum Standards of Procedural Justice in Administrative Adjudication, in International Investment Law and Comparative Public Law 39, 57 (Stephan W. Schill ed., 2010); Jan Wouters \& Nicolas Hachez, The Institutionalization of Investment Arbitration and Sustainable Development, in Sustainable Development in World Investment Law 615, 618 (Marie-Claire Cordonier Segger, Markus W. Gehring, \& Andrew Newcombe eds., 2011).

20 della Cananea, supra note 19 , at 57.

21 Lars Markert, Challenging Arbitrators in Investment Arbitration: The Challenging Search for Relevant Standards and Ethical Guidelines, 3 Contemp. Asia Ar B. J. 237, 243 (2010). Jan Paulsson, The Idea of Arbitration 17 (2013) [hereinafter Paulsson, The IDEA]; Susan D. Franck, Integrating Investment Treaty Conflict and Dispute Systems Design, 92 Minn. L. REv. 161, 214-215 (2007) [hereinafter Franck, Integrating Investment Treaty Conflict] (referencing empirical evidence which corroborates the positive effect procedural justice has on stakeholders' buy-in); Christopher Kee, Judicial Approaches to Arbitrator Independence and Impartiality in International Commercial Arbitration, in INvestment and Commercial Arbitration - Similarities and Divergences 181, 195 (Christina Knahr et al. eds., 2010).

23 Thomas M. Franck, The Power of Legitimacy among Nations 24 (1990) (framing legitimacy as the acceptance of and compliance with rules or institutions, based on the belief that "generally accepted principles of right process" are observed); Tномаs M. Franck, Fairness in International LaW and Institutions 7 (1995) [hereinafter Franck, Fairness] ("To be effective, the system must be seen to be effective. To be seen as effective, its decisions must be arrived at discursively in accordance with what is accepted by the parties as right process."); David D. Caron, Investor State Arbitration: Strategic and Tactical Perspectives on Legitimacy, 513 Suf Folk TransnAT'L. L.J., 514 (2008) [hereinafter Caron, Investor State Arbitration].

24 Catherine A. Rogers, The Ethics of International Arbitrators, in The Leading Arbitrators' Guide to International Arbitration 621, 630 (Lawrence W. Newman \& 
systems. Its importance is further underscored by the absence of a rule of precedent and the lack of an appeals mechanism ${ }^{25}$ in arbitration: The immense power which arbitrators wield ${ }^{26}$ is only acceptable if it is exercised in accordance with the law, in an objective, rational and open-minded way. In the context of investor-State arbitration, this is even more true in light of the important public interests which are frequently at stake. ${ }^{27}$ In the words of Van Harten:

[I]f one asserts that investment arbitration offers a fair, rules-based, and thus superior method of decision-making, then the system is appropriately held to a high standard of independence. ${ }^{28}$

Whether investor-State arbitration under the ICSID Convention fulfills this expectation is a matter of contention. An increasing number of disqualification

Richard D. Hill eds., 2d ed. 2008) [hereinafter Rogers, Arbitrator Ethics]. See also August Reinisch \& Christina Knahr, Conflict of Interest in International Investment Arbitration, in Conflict of Interest in Global, Public and Corporate Governance 103, 104 (Anne Peters \& Lukas Handschin eds., 2012); William W. Park, Arbitration's Discontents: Between the Pernicious and the Precarious, in Les relations privées internationales. Mélanges en l'honneur du Professeur Bernard Audit 581, 609 (2014) [hereinafter Park, Arbitration's Discontents] ("The raison d'être of arbitrator ethics... remains to enhance confidence in cross-border economic cooperation by bolstering the reliability of dispute resolution when a deal goes sour."); Susan D. Franck, The Role of International Arbitrators, ILSA J. INT'L. \& CoMP. L. 1, 6-7 (2006) [hereinafter Franck, The Role of International Arbitrators].

25 Schreuer, Dynamic Evolution, supra note 5, at 19.

26 Gus Van Harten, Investment Treaty Arbitration, Procedural Fairness, and the Rule of Law, in International Investment LaW and Comparative Public LaW 627, 627, 631, 637 (Stephan W. Schill ed., 2010) [hereinafter Van Harten, Procedural Fairness]; Santiago Montt, State Liability in Investment Treaty Arbitration: Global Constitutional and Administrative LaW in the bit Generation 139-140 (2009) (highlighting the legitimacy risk that ad hoc arbitration poses due to the inherent lack of coherence and consistency).

27 Charles N. Brower, The Ethics of Arbitration: Perspectives from a Practicing International Arbitrator (Keynote Address), 5 Berkeley J. Int'L. L. Publicist 1, 3 (2010), available at http://bjil.typepad.com/brower_final.pdf; Rogers, Arbitrator Ethics, supra note 24, at 648-649; Paulsson, The IdeA, supra note 22, at 147; Luke A. Sobota, Repeat Arbitrator Appointments in International Investment Disputes, in Challenges AND Recusals of Judges and Arbitrators in International Courts and Tribunals 293, 296, 312 (Chiara Giorgetti ed., 2015); Van Harten, Procedural Fairness, supra note 26, at 636-638.

Van Harten, Procedural Fairness, supra note 26, at 638. 
requests ${ }^{29}$ against ICSID arbitrators ${ }^{30}$ have led numerous scholars to analyze the issue in the past years.

ICSID challenge decisions have been scrutinized in an attempt to bring clarity to the standard of independence and impartiality contained in the ICSID Convention and Arbitration Rules. ${ }^{31}$ The standard and the threshold for challenges have been compared to corresponding standards in other dispute resolution mechanisms - in particular in commercial arbitration, less often in public international law adjudication - in the hope of coming up with an appropriate standard for ICSID arbitrators. ${ }^{32}$ Empirical analyses of whether ICSID arbitrators are biased have been conducted, by measuring the effect of extra-legal factors on the outcome of the proceedings, ${ }^{33}$ and by using specific

29 ICSID Convention art. 57. The referenced disqualification requests (also referred to hereinafter as arbitrator challenges or challenges) were based on allegations of a lack of independence or impartiality. See infra Chapter 2.

30 This book uses the term "ICSID arbitrators" to refer to arbitrators who are appointed to resolve disputes under the ICSID Convention.

31 See Markert, supra note 21, at 240; Sam Luttrell, Bias Challenges in International Commercial Arbitration: The Need for a "Real Danger" Test 224-237 (2009); James D. Fry \& Juan Ignacio Stampalija, Forged Independence and Impartiality: Conflicts of Interest of International Arbitrators in Investment Disputes, 30 Авв. INT'L. 189, 210-246 (2014); Reinisch and Knahr, supra note 24.

$3^{2}$ See Fry and Stampalija, supra note 31, at 194-198; Chiara Giorgetti, Challenges of International Investment Arbitrators: How Does it Work, and Does it Work?, 7 World ARB. \& Mediation Rev. 303 (2013) [hereinafter Giorgetti, Challenges]; Audley Sheppard, Arbitrator Independence in ICSID Arbitration, in International InVestment LaW For the 21St Century: Essays in Honour of Christoph Schreuer 131, 133-136 (2009); Noah Rubins \& Bernhard Lauterburg, Independence, Impartiality and Duty of Disclosure in Investment Arbitration, in Investment And Commercial Arbitration Similarities and Divergences 153 (Christina Knahr et al. eds., 2010); Nathalie Bernasconi-Osterwalder, Lise Johnson \& Fiona Marshall, Arbitrator Independence and Impartiality: Examining the dual role of arbitrator and counsel, IV ANNUAL FORUM FOR Developing Country Investment Negotiators, Background Papers, 8-16 (2010).

33 Susan D. Franck, Development and Outcomes of Investment Treaty Arbitration, 50 HARv. INT'L. L.J. 435 (2009) [hereinafter Franck, Development and Outcomes]; Susan D. Franck, Empirically Evaluating Claims About Investment Treaty Arbitration, 86 N.C.L. REv. 1 (2007) [hereinafter Franck, Empirically Evaluating Claims]; Daphna Kapeliuk, Collegial Games: Analyzing the Effect of Panel Composition on Outcome in Investment Arbitration, $3_{1}$ REv. Litig. 267 (2012) [hereinafter Kapeliuk, Collegial Games]; Daphna Kapeliuk, The Repeat Appointment Factor: Exploring Decision Patterns of Elite Investment Arbitrators, 96 CoRNELL L. REV. 47 (2010) [hereinafter Kapeliuk, Repeat Appointment]. 
indicators of potential bias, such as dissenting opinions $\mathrm{s}^{34}$ or jurisdictional rulings. ${ }^{35} \mathrm{~A}$ social network analysis of all arbitrators appointed to ICSID tribunals between 1972 and 2014 has visualized the different roles and close connections between investment arbitrators, and pointed out the independence and impartiality tensions this might entail. ${ }^{36}$

The described scholarship has yielded varying conclusions and solutions for the issues which were diagnosed. Some scholars have suggested that a different standard of independence and impartiality should be applied within the existing institutional framework. ${ }^{37}$ Others have detected a systemic bias in investment arbitrators which calls for fundamental reforms of ICSID arbitration. ${ }^{38} \mathrm{~A}$ third group of scholars argue that systemic bias is inevitable in investment arbitration, and that the system should be abolished, in order to give way to a permanent international investment court. ${ }^{39}$ For them, "[t]he most basic

34 Albert Jan van den Berg, Dissenting Opinions by Party-Appointed Arbitrators in Investment Arbitration, in Looking to the Future: Essays on International LaW in Honor of W. Michael Reisman 821 (2010) [hereinafter van den Berg, Dissenting Opinions]. Gus Van Harten, Arbitrator Behaviour in Asymmetrical Adjudication: An Empirical Study of Investment Treaty Arbitration, 50 Osgoode HALL L.J. 211 (2012).

36 Sergio Puig, Social Capital in the Arbitration Market, 25 Eur. J. INT'L. L. 387 (2014) [hereinafter Puig, Social Capital]. See also Daphna Kapeliuk, Social Capital and Arbitral Decision Making, EJIL: Talk! Blog of the European Journal of International Law (Sept. 24, 2014), http://www.ejiltalk.org/social-capital-and-arbitral-decision-making/; Thomas Stchultz, Comments on Sergio Puig's "Social Capital in the Arbitration Market", EJIL: Talk! Blog of the European Journal of International Law (Sept. 23, 2014), http://www.ejiltalk. org/comments-on-sergio-puigs-social-capital-in-the-arbitration-market/; Sergio Puig, Social Capital in the Arbitration Market, EJIL: Talk! Blog of the European Journal of International Law (Sept. 22, 2014), http://www.ejiltalk.org/12168/.

37 Bernasconi-Osterwalder, Johnson, and Marshall, supra note 32; G.J. Horvath \& R. Berzero, Arbitrator and Counsel: the Double-Hat Dilemma, 10 Transnat'L. Disp. Mgmt. (2013); PAulsson, The IDEA, supra note 22.

38 Wouters and Hachez, supra note 19, at 628; Stavros Brekoulakis, Systemic Bias and the Institution of International Arbitration: A New Approach to Arbitral Decision-Making, $4 \mathrm{~J}$. Int'L. Disp. Settrement 553, 553 (2013); Sundaresh Menon, Keynote Address, in ICCA Congress Series No. 17: International Arbitration. The Coming of a New Age? 6, 16 (Albert Jan van den Berg ed., 2013); Paulsson, The IdeA, supra note 22, at $348,35^{2}$.

39 Van Harten, Investment Treaty Arbitration, supra note 7, at 174-184 (highlighting that investment agreements emphasize host State obligations, but generally fail to clearly delineate the policy space that is left to host States, thereby reinforcing arbitrators' myopia in favor of investors); Gus Van Harten, Perceived Bias in Investment Treaty Arbitration, in The Backlash Against Investment Arbitration 433, 445 (Michael Waibel et al. eds., 2010) [hereinafter Van Harten, Perceived Bias]. Contra Stephen M. Schwebel, 
legal principle of any legal process, that justice must be blind, is clearly not at play here." ${ }^{40}$ Due to inherent methodological limitations of empirical research, however, scholars were unable to reliably prove or disprove bias in arbitral decision-making. ${ }^{41}$ Claims of actual dependence and bias therefore remain mere assumptions, which are based on perceptions, anecdotal evidence and individual experiences with extra-legal influences on arbitral decision-making. ${ }^{42}$

In summary, the existing scholarship on ICSID arbitrators' independence and impartiality has not managed to dispel concerns about procedural fairness, despite its remarkable recent growth. In particular, a workable standard of independence and impartiality is still not within reach.

This book therefore takes a different approach to the issue of ICSID arbitrators' independence and impartiality. It proposes two kinds of solutions. First, institutional reforms which would improve the effectiveness of tribunals' deliberations, reduce the number of challenges, and enhance the legitimacy of disqualification decisions are suggested. Second, the author recommends that a justifiable doubts standard should be applied to challenges of ICSID arbitrators, and makes proposals for the threshold's concrete application to potential conflict situations.

\section{Structure of the Book}

More specifically, this book approaches the topic as follows: Chapter 1 explores the ICSID Convention's provisions on arbitrators' independence and impartiality, arbitrators' disclosure obligations and the right of the disputing parties to remove unqualified arbitrators. It interprets the respective rules based on their regulatory intent and the drafting history, and clarifies vague expressions.

The Overwhelming Merits of Bilateral Investment Treaties, 32 Suffolk Transnat'L. L. REv. 263, 268-269 (2009).

40 Aaron Cosbey et al., Investment and Sustainable Development: A Guide to the Use and Potential of International Investment Agreements 13 (2004), http://www.iisd.org/pdf/2004/investment_invest_and_sd.pdf.

41 See Rogers, Politics, supra note 17, at 233. See also Thomas M. Franck, The Structure of Impartiality. Examining the Riddle of One LaW in a Fragmented WORLD 254 (1968) [hereinafter FrAnCK, STRUCTURE] ("Statistics on the voting behavior of World Court Judges do not, of course, support definitive statements on the state of the judicial psyche....To use an index of votes cast against the state of the judge's nationality as a scale for measuring his fairness may be like accusing a magistrate of nepotism because he has never jailed his wife."). 
Most importantly, the strained relationship between the requirement of independence and impartiality and the party-appointment of decision-makers is analyzed, and the scope of both concepts in the context of ICSID arbitration is delineated in abstract terms.

Chapter 2 examines how past disqualification decisions have delimited the requirement of ICSID arbitrators' independence and impartiality. As the parties' primary enforcement mechanism for their right to an independent and impartial decision-maker, arbitrator challenges are "essential to the integrity of the international arbitral process." ${ }^{33}$ The burden of proof imposed on parties in this context is decisive for the effectiveness of their right. Thus, the question at the center of this Chapter is whether the challenge case law of ICSID tribunals has led to the crystallization of a clear and predictable threshold for arbitrator challenges. Such a uniform threshold might arise from the consistent use of the same terminology and the uniform application of the same abstract criteria. Or it might only manifest itself in its application to specific case categories. Both possibilities are examined in separate parts of Chapter 2.

Chapter 3 examines the rules and case law of other dispute resolution mechanisms relating to independence and impartiality. The comparative analysis of the standards applied and outcomes achieved in other fields, which are related to ICSID arbitration, serves firstly as a benchmark to further refine the evaluation of ICSID removal proceedings, and secondly as an inspiration for possible alternative approaches to improving procedural fairness. As in Chapter 2, the focus of the analysis is on the grounds for challenge and the threshold applied in other words, the degree of independence and impartiality expected of arbitrators. ${ }^{44}$ Unlike most other comparative studies, this work does not merely juxtapose the abstract standards and thresholds of other mechanisms to the ICSID rules and case law. Wherever case law on disqualification requests in these systems is available, such decisions are analyzed, and the handling of specific conflict categories is compared to their assessment in the ICSID system. This allows for an informed and detailed comparison of challenge outcomes in the examined systems at the end of Chapter 3.

A significant constraint on the research for Chapters 2 and 3 is the scarcity of published decisions on arbitrator disqualifications. Confidentiality as an important principle in arbitration means that many arbitration institutions do not publish challenge decisions, just like awards are not always

\footnotetext{
43 W. Michael Tupman, Challenge and Disqualification of Arbitrators in International Commercial Arbitration, 38 INT'L. \& CoMP. L.Q. 26, 26 (1989).

44 Technicalities of the appointment, disclosure and challenge process (i.e. delays for challenges) are not examined.
} 
published. Some institutions only publish the outcome of decisions on disqualification requests, and not the reasons, which significantly hinders the above-mentioned analysis. Furthermore, under all arbitration mechanisms, parties may confront potentially biased arbitrators before filing a challenge. Arbitrators sometimes resign upon such an informal "challenge." 45 Since no decision is rendered, resignations (and their reasons) are impossible to grasp. Despite these obstacles, the first two Chapters of this book offer a first comprehensive (subject to the just mentioned qualifications) analysis of existing challenge decisions in the examined dispute settlement mechanisms. As such, they facilitate a substantiated evaluation of the current criticism of ICSID disqualification proceedings, and of the solutions for improving procedural fairness hitherto proposed.

Chapter 4 evaluates reform proposals which have been made to date. It rejects the suggestion of abolishing party-appointments of arbitrators, or limiting the parties' choice of arbitrators to a roster. A prohibition of dual functions (serving both as an arbitrator and as a counsel to arbitration parties) is also dismissed. On the other hand, the author supports the call for a clarification of the threshold for arbitrator challenges, and corroborates why a justifiable doubts test is appropriate. The European Union's initiative for an Investment Court System as the most tangible reform proposal is outlined and scrutinized.

Acknowledging the need for more specific adjustments to bolster the perception of the ICSID system's legitimacy, Chapter 5 presents some novel proposals - both on the institutional level, and with regard to the handling of arbitrator challenges in specific conflict situations. On the institutional level, the appointment of the chairperson of the tribunal from a closed roster is suggested. This requirement aims to ensure the chairperson's experience, authority and demonstrated neutrality, which will foster her or his ability to effectively include both party-appointed arbitrators into the tribunal deliberations. Chapter 5 further suggests that ICSID arbitrators should continue to be nominated by the disputing parties, but require the institution's confirmation, which would be subject to the absence of certain (narrowly framed) compulsory grounds for disqualification. In the context of such a confirmation proceeding, parties should also be able to raise objections based on grounds

45 Judith Levine, Dealing with Arbitrator "Issue Conflicts" in International Arbitration, DisP. Resol. J. 61, 63 (2006); Markham Ball, Probity Deconstructed: How Helpful, Really, are the New International Bar Association Guidelines on Conflicts of Interest in International Arbitration? 21 ARB. InT'L. 323, 326 (2005); Marie Öhrström, Decisions by the scc Institute Regarding Challenge of Arbitrators, Stockholm Arbitration Report 35, 35 (2002). 
which would entitle them to challenge the arbitrator later. Last but not least, the author proposes that disqualification requests filed after the commencement of the proceeding should be evaluated by the same institutional body, instead of the unchallenged arbitrators. In a second part of Chapter 5 , the need for ICSID-specific conflict of interest guidelines is highlighted, and a first proposal for the assessment of specific conflict situations is made. 